\title{
The Enrichment Culture, Screening and Purification of Oil Degradation Bacteria from Contaminated Seawater and Drilling Mud
}

\author{
Wu Zhang ${ }^{1}$, a, Yanyan $\mathrm{Ji}^{2}$, b, Ling $\mathrm{Li}^{1}$, and Hongyan Yang ${ }^{1}$ \\ ${ }^{1}$ College of Marine and Environment Science, Tianjin Key Laboratory of Marine Resources and \\ Chemistry, Tianjin University of Science and Technology, Tianjin 300457, P. R. China \\ ${ }^{2}$ School of Environmental and Chemical Engineering, State Key Laboratory of Hollow Fiber \\ Membrane Materials and Processes, Tianjin Polytechnic University, Tianjin 300387, P. R. China
}

azhangwu@tust.edu.cn, bjiyanyan@tjpu.edu.cn

Keywords: Marine oil pollution, Oil degradation bacteria, Bio-treatment, Enrichment culture.

Abstract. It is urgent to find a reliable technique to settle the problem along with growing of petroleum hydrocarbon pollution in the sea. Compared to other traditional methods, biological treatment has a significant advantage. It is the key factor that gets bacteria with high efficiency of hydrocarbon degradation. In this paper, several oil degradation bacteria were isolated from indigenous colony through enrichment culture, domestication, screening and purification, in which the contaminated seawater and oil drilling mud were selected as sources. And the Gram staining was used to identify above bacteria. Appropriate conditions were exploited to preserve the strain. The present work has provided a foundation for the further research on oil degradation performance.

\section{Introduction}

Oil spill accidents arose and polluted sea area expanded along with the rapid increase of petroleum production, refining and maritime transport [1-2]. So it is necessary to exploit effective technology for eliminating oil pollution, which can provide well protection on health of human being and facilitate the development of tourism and marine aquaculture.

The technique to eliminate oil pollution included physical method [3] (oil tanker, oil boom, sorption materials), chemical method [4] (oil dispersant) and the biological method (hydrocarbon degrading bacteria) etc. It was difficult to remove the dissolved oil into water and the oil film on the surface of the water by using physical method. The secondary pollution would be produced by chemical method through introducing chemical pollutants into seawater. Compared with above method, bio-treatment technology could effectively eliminate oil film at surface and decompose dissolved oil in water [5-7], which took less influence on human beings and the environment. Meanwhile the cost of bio-treatment was only $30 \sim 50 \%$ of traditional physical, chemical repair. The use of microbial technology to eliminate marine oil pollution shows a broad application prospect [8-9].

Bioremediation gradually becomes the key technology on removing oil pollution since the development of the biotechnology [10]. The screening, enrichment and purification on dominant indigenous degradation bacteria from typical oil pollution area were reported in present article, which lay a solid foundation for next work.

\section{Experiment}

\section{Material.}

Sample Containing Oil. The seawater contaminated with petroleum hydrocarbon was taken from Beitang dock of Tianjin. The oil mud was obtained from waste drilling fluid pool of Tianjin Bihai Environmental Service Center of CNOOC (China National Offshore Oil Corporation).

Enrichment Culture Solution. Retail $0^{\#}$ diesel $\left(0.835 \mathrm{~g} / \mathrm{cm}^{3}\right): 1 \%$ volume concentration. $\mathrm{KH}_{2} \mathrm{PO}_{4}: 0.01 \mathrm{~g} / \mathrm{L}$. $\left(\mathrm{NH}_{4}\right)_{2} \mathrm{SO}_{4}: 5.0 \mathrm{~g} / \mathrm{L}$. Aging seawater.

Diesel Plate Medium. Peptone: $2.0 \mathrm{~g} / \mathrm{L}$. Yeast extract: $0.5 \mathrm{~g} / \mathrm{L}$. Diesel: 1\%volume concentration. $\mathrm{K}_{2} \mathrm{HPO}_{4} \cdot 3 \mathrm{H}_{2} \mathrm{O}: 0.4 \mathrm{~g} / \mathrm{L} . \mathrm{KH}_{2} \mathrm{PO}_{4}: 0.6 \mathrm{~g} / \mathrm{L}$. $\left(\mathrm{NH}_{4}\right)_{2} \mathrm{SO}_{4}: 2.0 \mathrm{~g} / \mathrm{L}$. Agar: $\%$. Aging seawater. 
Sampling. The samples should be collected on behalf of the local environmental characteristics. As much preventive measure as possible should be taken to guarantee sample not be affected by pollution and the composition not be changed during the period from collecting sample to laboratory analysis.

As described above, samples for screening indigenous bacteria were obtained from two locations: (1) Beitang dock of Tianjin, (2) Tianjin Bihai Environmental Service Center of CNOOC (China National Offshore Oil Corporation). Fig. 1 showed the photos of sampling point.

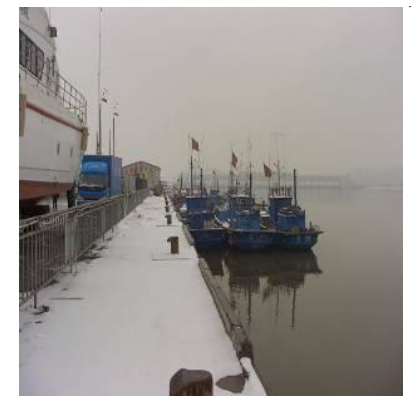

a)

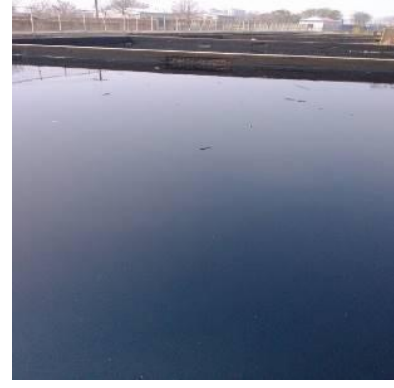

b)

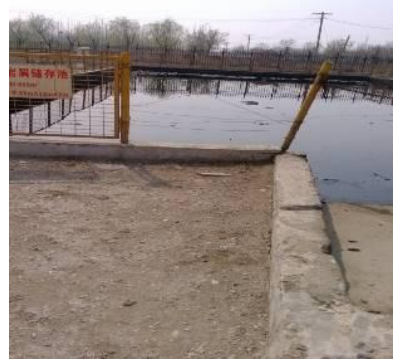

c)

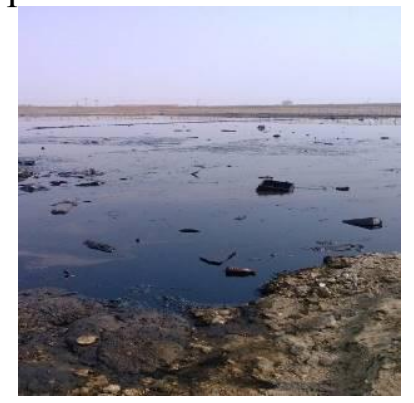

d)

Fig. 1 a) seawater from location 1, b) slurry from location 2, c) dry soil from location 2, d) deposits from location 2.

Enrichment culture. The principle of enrichment culture was based on which each of microbes has their respective laws of life activities. Only the microorganisms that adapt specific environmental conditions well could keep growing vigorously. The pure culture of target microorganisms which become the dominant species would be obtained under the conditions not suitable for other microbar's growth.

$100 \mathrm{ml}$ culture (containing diesel: $8.35 \mathrm{~g} / \mathrm{L}, \mathrm{KH}_{2} \mathrm{PO}_{4}: 0.01 \mathrm{~g} / \mathrm{L},\left(\mathrm{NH}_{4}\right)_{2} \mathrm{SO}_{4}: 5.0 \mathrm{~g} / \mathrm{L}$, aging seawater) was taken into six Erlenmeyer flask which named number 1 6. $1 \mathrm{ml}$ diesel was added to No. 1, 2, 5th bottle, which were sterilized $20 \mathrm{~min}$ at $121^{\circ} \mathrm{C}$.

$10 \mathrm{~g}$ Sample 1 was introduced into No.1 and No.2 culture under sterile operation, one of which was the control bottle. $10 \mathrm{~g}$ and 20g Sample 2 were introduced into No.3 and No.4 culture respectively, which could be used to investigate the concentration gradient. Similar, 10g Sample 3 was added into No. 5 culture and 10g Sample 4 was added into No.6 culture. All above cultures were enriched for 7 days at $25^{\circ} \mathrm{C}$ on a constant temperature water bath-shaker.

Spread-Plate Technique. Dilute spread plate was a method that coat bacteria solution with gradient dilution evenly on the surface of the solid medium. Microorganism that came together by enrichment could be dispersed into individual cells when dilution ratio was high enough, and then a single bacteria colony would be formed on the surface of the medium.

Spread plate was operated on diesel plate medium (peptone: $2.0 \mathrm{~g} / \mathrm{L}$, yeast extract: $0.5 \mathrm{~g} / \mathrm{L}$, diesel: $8.35 \mathrm{~g} / \mathrm{L}, \mathrm{K}_{2} \mathrm{HPO}_{4} \cdot 3 \mathrm{H}_{2} \mathrm{O}: 0.4 \mathrm{~g} / \mathrm{L}, \mathrm{KH}_{2} \mathrm{PO}_{4}: 0.6 \mathrm{~g} / \mathrm{L},\left(\mathrm{NH}_{4}\right)_{2} \mathrm{SO}_{4}: 2.0 \mathrm{~g} / \mathrm{L}$, agar: $\left.16 \mathrm{~g} / \mathrm{L}\right)$.

The original solution of sample 1, 4, 5 and 6 was spread by using plate method in which dilution ratios were $10^{2}, 10^{4}$ and $10^{6}$ respectively, which was cultured $48 \mathrm{~h}$ at $26^{\circ} \mathrm{C}$.

Streak plate. Streak plate was the method that different cells of same microbial groups or mixed microorganisms were separated into individual cells with independent distribution. After culturing, individual cells grew into single colony, which were identified as the purified bacteria. The single colony not always consisted of individual cell, so purified microbial was obtained by separating many times repeatedly.

Slant culture. Slant culture was a form of solid medium, which was made by quantitative packing in vitro containing hot. The fixed slant was shaped after cooling solidification on an incline. It can be used the expansion and preservation of bacteria. The formula of diesel slant culture medium was same with diesel plate medium. Cultured $48 \mathrm{~h}$ at $26^{\circ} \mathrm{C}$.

Preservation of bacteria. Bacteria were inoculated on solid slant medium. After bacteria grew adequately, the tampon was covered well by oilpaper. Above system was preserved at $2 \sim 8^{\circ} \mathrm{C}$ in a refrigerator. 
Gram staining method. The purified individual bacteria were dying based on Gram staining, which can provide the identification on Gram negative or positive performance.

\section{Result and Discussion}

Domesticating of petroleum hydrocarbon degradation bacteria. Some quantitative sample containing oil was introduced into $100 \mathrm{~mL}$ culture solution under sterile operation, which was enriched $7 \mathrm{~d}$ at $26^{\circ} \mathrm{C}$ on shaking bath. Then shake well and half of above culture was transferred into $50 \mathrm{~mL}$ fresh culture, which was kept culturing $7 \mathrm{~d}$ in above conditions.

The solution showed turbid state after enrichment of two weeks, which suggest that the domesticated oil degradation bacteria multiplied rapidly and abounded in the enrichment culture solution.

Separation and purification of petroleum hydrocarbon degradation bacteria. The oil degradation bacteria were separated on diesel plate medium by streak plate method and then different individual bacteria was purified.

Ten individual oil degradation bacteria were obtained through repeat streak plate. Oil degradation bacterium 1-1, 1-2 and 1-3 were isolated from Sample 1. Oil degradation bacterium 4-1 and 4-2 were isolated from Sample 2. Oil degradation bacterium 5-1 and 5-2 were isolated from Sample 3. Oil degradation bacterium 6-1, 6-2 and 6-3 were isolated from Sample 4.
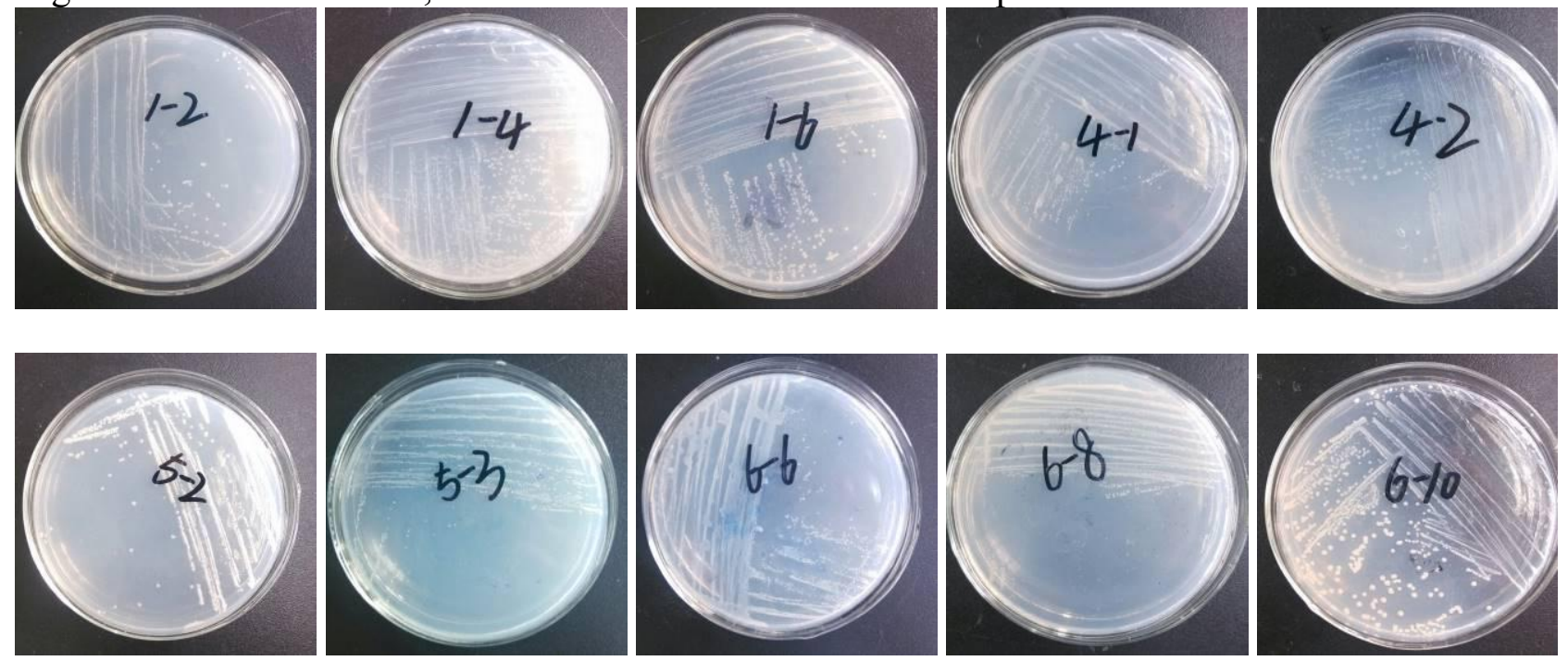

Fig. 2 The ten individual oil bacteria through repeat streak plate.

Fig. 2 showed the process of streak plate. The isolated bacteria were preserved with diesel slide culture medium at $4^{\circ} \mathrm{C}$ in refrigerator.

Gram stain. The purified individual bacteria were dying based on Gram staining, which can provide the identification on Gram negative or positive performance. Ten individual oil degradation bacteria that were obtained in this work were identified to be gram-positive bacteria. Fig. 3 showed the photos of bacteria after dying under microscope.

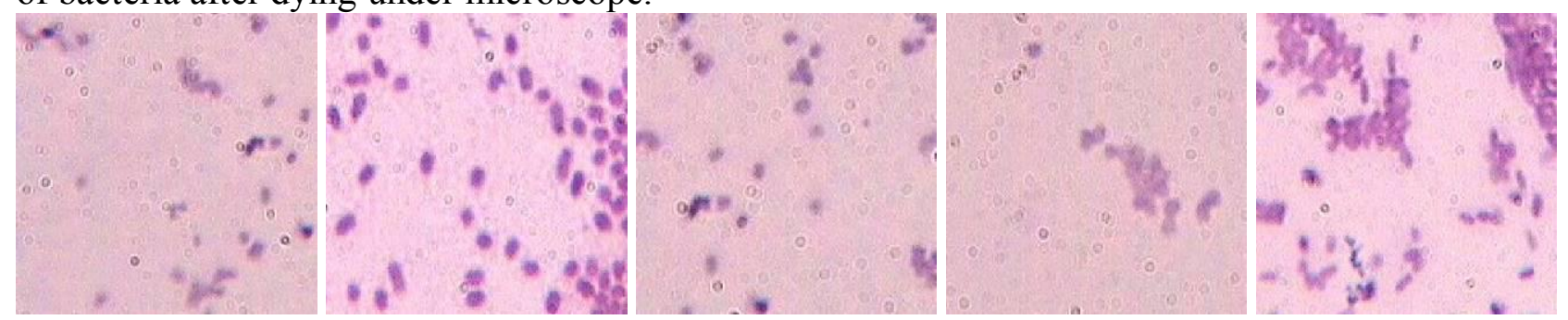




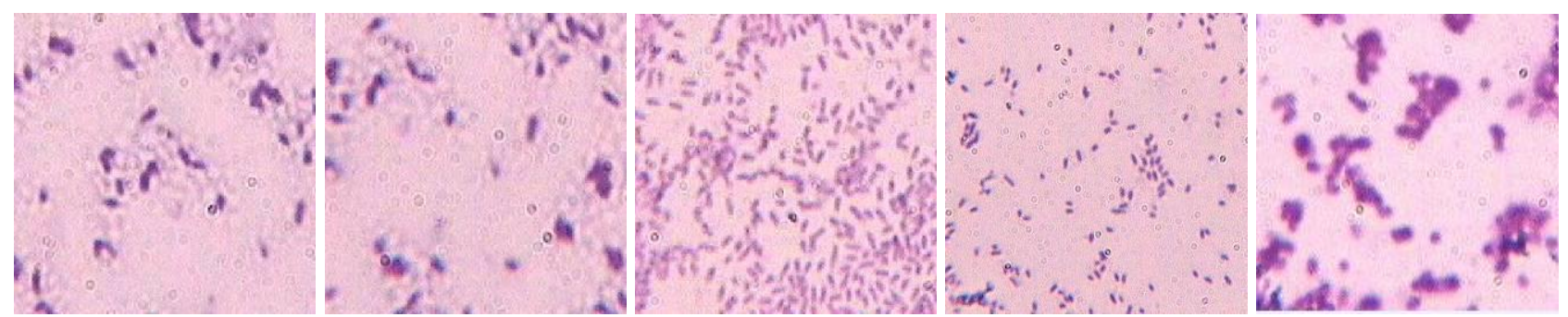

Fig. 3 The photos of bacteria after dying under microscope.

\section{Conclusions}

In this paper, the seawater contaminated with oil and oil field drilling cuttings were took as resource, the dominant petroleum hydrocarbon degradation bacteria were screened from indigenous strains based on traditional enrichment and domestication method with suitable culture medium. The oil degradation bacteria were separated by streak plate and then ten kinds of purified bacteria were obtained. All above strains were identified to be gram-positive bacteria. This work provided a solid foundation for obtaining dominant with well oil degradation performance and the retail research would be developed in our follow-up work.

\section{Acknowledgements}

This work was financially supported by the Youth Fund of National Natural Science Foundation of China (51503148), Tianjin Research Program of Application Foundation and Advanced Technology (15JCQNJC09000, 14JCQNJC02500), the Foundation for Outstanding Young Teachers in Tianjin Higher Education Institutions (TJYQ2013050012) and Youth Innovation Fund of Tianjin University of Science and Technology (Science \& Research) (2014CXLG13).

\section{References}

[1] E.A. Dubinsky, M.E. Conrad, R. Chakraborty and G.L. Andersen: Environ. Sci. Technol. Vol. 47(2013), p. 10860

[2] X.X. Zhang, W.L. Wu, Y.B. Zhang, and G.J. Lu: Ind. Eng. Chem. Res. Vol. 46 (2007), p.8910

[3] M.B. Ripley, A.B. Harrison, W.B. Betts, R.K. Dart and A.J. Wilson: Environ. Sci. Technol. Vol. 34 (2000), p. 489

[4] A. Fiorentino, A. Gentili, M. Isidori and F. Temussi: J. Agric. Food Chem. Vol. 52 (2004), p. 5151

[5] R.F. Lamberts, J.H. Christensen, P. Mayer, O. Andersen and A.R. Johnsen: Environ. Sci. Technol. Vol. 42 (2008), p. 4790

[6] H.M. Jin, J.M. Kim, H.J. Lee and C.O. Jeon: Environ. Sci. Technol. Vol. 46 (2012), p. 7731

[7] D.B. Mao, R. Lookman and L.D. Diels: Environ. Sci. Technol. Vol. 43 (2009), p. 7651

[8] H.Y. Gong, M.T. Bao, G.L. Pi, Y.M. Li, A.Q. Wang and Z.N. Wang: ACS Sustainable Chem. Eng. Vol. 4 (2016), p. 169

[9] M. Natter, J. Keevan, Y. Wang, A.R. Keimowitz, B.C. Okeke, A. and Ming-Kuo Lee: Environ. Sci. Technol. Vol. 46 (2012), p. 5744

[10] L. Lapham, L. Proctor and J. Chanton: Environ. Sci. Technol. Vol. 33 (1999), p. 2035 